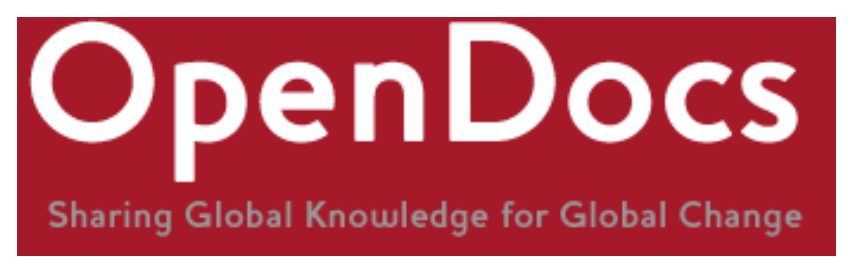

Title: Unearthing treasure and trouble: mining as an impetus to urbanisation in Tanzania

Citation: Bryceson, D., Jonsson, J., Kinabo, C., and Shand, M. (2012) Unearthing treasure and trouble: mining as an impetus to urbanisation in Tanzania. Journal of Contemporary African Studies, 30 (4), pp. 631-649. DOI: 10.1080/02589001.2012.724866

Official URL: http://dx.doi.org/10.1080/02589001.2012.724866

More details/abstract: Despite an abundance of mineral wealth and an ancient history of gold trading, Tanzania is a relative latecomer to the experience of being a mineral-dominated national economy. Both the British colonial state and Nyerere's post-colonial state avoided encouraging, and only reluctantly provided support to, large and small-scale mining. Farming constituted the livelihood for the vast majority of the population and peasant agricultural exports provided the main source of foreign exchange for the country. Now, however, Tanzania has become one of Africa's main gold producers and the number one destination for non-oil foreign direct investment after South Africa. This article traces the development of gold mining and urban growth in Tanzania with the aim of identifying if, when and where these two processes interact with one another. We explore the triggers, mechanisms and durability of their fusion and synergies over time.

Version: Accepted version

Terms of use: This is an Accepted Manuscript of an article published by Taylor \& Francis Group in Journal of Contemporary African Studies 17/10/2012, available online: http://dx.doi.org/10.1080/02589001.2012.724866

There may be differences between this version and the published version. You are advised to consult the publisher's version if you wish to cite from it:

This is a download from OpenDocs at the Institute of Development Studies

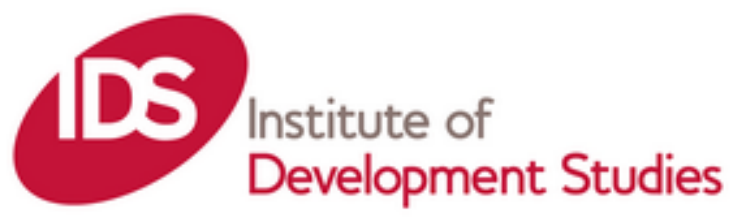


Special Issue of the Journal of Contemporary African Studies, vol 30(4), $631-49$ (editors: D.F. Bryceson \& D. MacKinnon)

\title{
Unearthing treasure and trouble: Mining as an impetus to urbanisation in Tanzania
}

\author{
Deborah Fahy Bryceson \\ Jesper Bosse Jønsson \\ School of Geographical and Earth Sciences, University of Glasgow, Scotland, UK. \\ Crispin Kinabo \\ Department of Geology, University of Dar es Salaam, Tanzania \\ Mike Shand \\ School of Geographical and Earth Sciences, University of Glasgow, Scotland, UK.
}

\begin{abstract}
Despite an abundance of mineral wealth and an ancient history of gold trading, Tanzania is a relative latecomer to the experience of being a mineral-dominated national economy. Both the British colonial state and Nyerere's post-colonial state avoided encouraging, and only reluctantly provided support to, large and small-scale mining. Farming constituted the livelihood for the vast majority of the population and peasant agricultural exports provided the main source of foreign exchange for the country. Now, however, Tanzania has become one of Africa's main gold producers and the number one destination for non-oil foreign direct investment after South Africa. This article traces the development of gold mining and urban growth in Tanzania with the aim of identifying if, when and where these two processes interact with one another. We explore the triggers, mechanisms and durability of their fusion and synergies over time.
\end{abstract}

Keywords: mining history; gold; mineral depletion; large-scale mining; small-scale mining; urban growth; urban hierarchy; Tanzania.

The search for a better life has propelled millions of Tanzanians to migrate from rural homelands to urban areas since national independence in 1961. With the steady erosion of peasant farmers' terms of trade over the last 30 years, members of farming households have been re-evaluating their links to the land (Bryceson 2009). Increasingly many have come to see the countryside as a poverty trap from which they seek escape. Formerly, most were attracted to the capital city, or nearby secondary cities. Now many migrate to mining areas, usually located in remote rural areas. Over time, however, the pressure of population amassing at the mineral-bearing locality is likely to generate urban growth. Mineral depletion can set in train a converse process of depopulation and impoverishment. The first to be affected are the small-scale miners ${ }^{1}$ and their dependents with reverberating impacts on service providers.

In this contribution, we trace mining and urbanisation's impact on the Tanzanian population and economy with respect to urban population densification, economic diversification and social stratification. Our aim is to identify where and when mineral production and trade in Tanzania catalysed interactive processes and synergies between mining and urbanisation, paying particular attention to the intensity of the synergy affected by the high monetary value of the extracted minerals destined for global markets relative to the low level of economic welfare of the majority of the national population. Conversely, mining and urbanisation synergies are anticipated to weaken as the mineral supply dissipates and/or the market value of the minerals declines.

By deploying the term synergy we are not inferring that the interactive processes are simple, formulaic straight-line paths to urbanisation. Far from it, the dynamics are complex and liable to instability and reversal due to internal imbalances or negative external stimuli as inferred in the juxtaposing of 'treasure' and 'trouble' in the title of this contribution. The welfare of urban residents is most at risk. Migrants are attracted to mining settlements with expectations of material gain, but the 
reality is that people necessarily lead highly competitive, risky lives. Access to livelihood, services and basic social needs within the urban community are uncertain.

Large-scale mining corporations' investments are likely to catalyse urban growth in developing country contexts often preceded by activities pioneered by small-scale miners and other local agents. The latter's migration to mineral rich localities is energised by the implicit hope of narrowing the gap between perceived local and global economic differences. In the case of gold such aspirations are not unreasonable. The world price of gold has climbed to an unprecedented level, at the same time as small-scale miners have been able to keep informed of world prices and use that information to bargain for better gold prices.

Our objective is to probe urbanisation in relation to small and large-scale mining in Tanzania. The first section focuses on mining history, notably the peaks of urban growth and mining activities of the $13^{\text {th }}-14^{\text {th }}$ centuries when Kilwa Kisiwani, an island off the Tanzanian coast, was famed for its urban opulence and splendour as the gold entrepot of East Africa. Thereafter our historical review moves forward in time to Tanzanian mining developments in the $19^{\text {th }}$ and $20^{\text {th }}$ century, specifically at two gold-producing settlements, Lupa and Geita. Tracing Tanzania's entwined mine-led migration and urbanisation history, the country's urban growth pattern and the resultant urban hierarchy are discussed in light of Kuntuly's concept of depolarisation and differential urbanisation. Turning to the significance of settlements with secondary connections to gold mining, we interrogate how serviceprovisioning activities form part of the geographical spread of mining's urbanising influences and provide possible exemplars for mining towns facing mineral depletion. Our conclusion raises questions regarding the sustainability of individual mine-led urban settlements and Tanzania's urban future more generally.

\section{Kilwa: Gold-rich global city of the $13^{\text {th }}-14^{\text {th }}$ centuries}

Kilwa's fame as the East African coast's main trading centre for the export of Zimbabwean gold is linked to the emergence of an extremely cosmopolitan form of urbanism in East Africa at the beginning of the $12^{\text {th }}$ century, peaking between 1250 and 1350, before ebbing away with dwindling gold production in Zimbabwe. None of the gold trade was known to be sourced from Tanzania. Rather it was mined and transported from Zimbabwe and Manicaland overland to Sofala in Mozambique, then shipped northwards in small boats up the Swahili coast to Kilwa, where it was loaded on larger vessels destined for the Middle Eastern and Indian gold markets. Kilwa's transshipment harbour was strategically situated for larger sea vessels travelling to and from India which relied on seasonal monsoon winds. Further south along the Mozambican coastline, the winds were too weak for the large sea-going vessels (Pearson 1998).

In a period when European cities were just beginning to distinguish themselves from Europe's feudal countryside, Kilwa was in effect a global city of the medieval period. The Madhali dynasty built the domed extension of the Great Mosque and the enormous palace and extensive trade depot of Husuni Kubwa in the early $14^{\text {th }}$ century, which is unsurpassed in coastal Swahili architecture, incorporating many exotic Middle Eastern design features found elsewhere in the Islamic world (Mitchell 2005). Its construction is estimated to have taken place between 1315 and 1330 when the world price of gold was peaking under the sultanate of Al-Hassan bin Sulaiman (Moon 2005). At the time, the explorer Ibn Battuta (1962) remarked that Kilwa ranked as one of the most well constructed and visually pleasing towns in the world.

Nonetheless, at its peak of urban sophistication, Kilwa became subject to the fluctuation of gold prices. The Black Death caused a sudden, sharp fall in the world gold price in Europe and beyond in the 1340s. While demand waned, the supply of Zimbabwean gold was diminishing, undermining Kilwa's gold economy and prosperity, as suggested by the prolonged state of disrepair of the dome in the Great Mosque (Moon 2005). Many decades passed before the Great Mosque's dome was repaired and new building works were started in the early $15^{\text {th }}$ century. Foreign visitors were again impressed in the $16^{\text {th }}$ century (Pearson 1998), noting the extravagance of the jewellery and clothing of the stone town's elite population.

At the time of the arrival of the Portuguese in East Africa in 1498, Kilwa was estimated to have a population of 5,000 to 10,000 people. Already there were outward signs of declining wealth and 
waning trading dominance. ${ }^{2}$ The Portuguese seized Kilwa in 1505 and built a fort (gereza) but relinquished the island in 1512, favouring Mombasa as their East African naval base. ${ }^{3}$

Today, Kilwa has a very small village settlement mostly of fishermen. Its majestic ruins attract foreign tourists in small numbers but its connection to an international gold trade is largely forgotten. The significance of gold does not reappear in Tanzanian history for almost four centuries.

\section{Mining in the $19^{\text {th }}$ and $20^{\text {th }}$ centuries}

Since colonial intrusion in 1888 right up to the 1990s, Tanzania's economic potential was primarily perceived in terms of its surface land, soils, water resources, and wildlife. Agriculture was the economic foundation of the country, with tourism only gaining significance during the 1980s and 1990s as peasant agriculture declined. The country's mineral resources: gold, diamonds and a variety of precious stones and industrial minerals were not taken into account or planned for, despite the country's economic poverty.

Nonetheless, a century before, German colonists' mineral prospecting had revealed mica, copper, iron, lead, iron and zinc at various locations in the territory. In 1898 the German company, Koncession für Edelmineralien, discovered gold at Saragura Hill in the northwestern part of the country, 15 kilometres from where Geita town is situated today (Chachage 1995). Shallow level production was initiated, but as gold prices were low and World War I loomed on the horizon, they did not proceed to deep level mining (Lemelle 1986). Similarly, gold was discovered at Sekenke in 1906 and production began in 1909. The following year nearly a ton of gold was extracted from the mine with the work force expanding to 20 European and 700 locally recruited workers soon thereafter.

German East Africa became the site of intense armed conflict between German and British-led troops during World War I, putting a stop to all forms of mining. In the transition from German to British rule, there was a hiatus in titled property ownership. Holding a League of Nations mandate to administer the territory, the colonial state, which was legally obliged to give precedence to African interests over those of non-indigenous settlers, avoided encouraging or supporting European mining initiatives. Geo-politically, the tense interwar period, in which German imperial interests re-emerged under Hitler's leadership, left potential venture capitalists doubtful about the security of their investments in Tanganyika (Lemelle 1986). Thus, a significant amount of the mining activity that took place during the 1920s and 1930s under British rule arose in the context of declining agricultural prices and soaring gold prices during a world depression.

\section{Lupa, Geita and beyond: Mine rush towns}

The discovery of gold at Lupa in 1922 in a remote part of southwestern Tanganyika triggered the territory's first gold rush. Lupa was an arid, uninhabited and inaccessible plain in the mid-1920s, when the gold rush began. From a mere trickle of non-native diggers and their African labour, the Lupa gold field grew to a population of more than 20,000 by the mid-1930s. The number of Europeans expanded from 150 in 1922 to over 1000 in 1936, with the African diggers, many of whom came from the neighbouring countries of Malawi, Kenya, and Zambia and some as far away as Zimbabwe being in the majority (Dickson 1925; Lemelle 1986; Bryceson 1990). By the early 1930s, Lupa had gained the reputation of being Tanganyika's urban slum. With diggers and labourers continuing to pour in, sanitation and food supplies were stretched far beyond the limits of public health. Scurvy was rife and the prices of basic foodstuffs were exorbitant. Despite deplorable conditions at Lupa, the government was slow to take action amidst the Depression. In 1935, a road was built to facilitate the transport of food. The Lupa gold rush had a magnetic force on the settlement pattern of Mbeya region. Men attracted to the gold fields for mining were followed by others eager to provide tertiary services and foodstuffs (Roberts 1986). Official gold production in Tanzania went up from 467 kilos in 1928 to 1711 kilos in 1934 (Lemelle 1986, 125).

Mining in the Lupa gold fields was dominated by alluvial mining until 1939 when reef mining started exceeding alluvial mining output (Roberts 1986). At the outset of the rush, gangs of young Africans worked for their white bosses. However, the 1929 Mining Ordinance gave all those who 
could afford 10 shillings and could fill out a form the possibility to apply for a prospecting licence. Thus from the 1930s, African miners started to access prospecting rights themselves (Lemelle 1986). Large-scale production from the reef mines around Lake Victoria, predominantly at Geita, Musoma and Sekenke gained pace from around 1930. Geita Mine became the largest gold producer in the region in 1936. Settlement conditions for the African miners were better there. Geita Mine, in particular, was officially viewed as a model workplace with respect to its provision of a balanced daily diet of cooked food for the workers and living conditions (Tanganyika Territory 1938; Thompson 1936).

The late 1930s were golden years for the Tanganyikan colonial mining sector. Gold production peaked at four tonnes in 1939, largely due to high world market prices that prevailed during the global recession. Gold exports became a significant contributor to the territory's economy, constituting almost $20 \%$ of export earnings in the late 1930 s, ${ }^{4}$ creating employment for and tax income from miners. In 1938, a committee under the colonial administration estimated that there were 32,000 Africans involved with mining in Tanganyika, $85 \%$ in gold with the majority (73\%) working as smallscale miners in Lupa (Lemelle 1986). ${ }^{5}$ Already in those early years, it was clear that small-scale mining was more labour absorbing than large-scale mining.

During World War II, prospecting was banned (from 1941) and many mines first cut down on their production and subsequently closed down altogether due to labour shortages and difficulties in accessing supplies (Roberts 1986). When the gold mines in Tanganyika resumed production after the war it was at a lower scale with annual production at two tonnes and mineral exports constituting only $5 \%$ of export earnings. In the late 1940s and into the 1950s many gold mines closed and the ones that continued to produce gold, especially Geita Mine, faced financial problems. Most other small gold mines, in Chunya, Mpanda, Buhemba, Kahama and Nzega districts, also struggled financially during the 1950s (Chachage 1995).

In 1961 Tanzania attained national independence. Despite gold, diamond, and gemstone discoveries during the colonial period, President Nyerere, as father of the nation, was reluctant to pursue exploitation of the country's mineral wealth or see minerals as foundational to national economic growth. During the first years after independence, various mines continued production. At the same time new discoveries of gemstones (e.g. tanzanite, ruby, sapphire, alexandrite and emerald) and gold were made at several locations. However, with the closure of the Geita Mine in 1966, largescale gold mining ended. From 1967, Tanzania embarked on a path of central planning and nationalisation of most of the country's mines to form a state-controlled mining sector run by the state-owned mining corporation STAMICO. Official gold production declined from three and a half tonnes in the mid-1960s to ten kilos in the early 1970s. This however masks the fact that many of the Tanzanians, who had been employed in gold and gemstone mines, continued to mine with rudimentary tools, and smuggled their produce out of the country, mainly to Nairobi in Kenya. Smallscale miners' activities during the 1960s and 1970s were clandestine, taking place beyond the control of STAMICO in remote parts of the country (Drechsler 2001). At the end of the 1970s, Tanzania's mining sector consisted of a few dysfunctional industrial mines and scattered small-scale miners numbering probably somewhere between 10,000 and 50,000.

\section{National gold rush momentum}

With the promulgation of Tanzania's first post-independence mining legislation, the Mining Act of 1979, the Government of Tanzania abandoned its insistence on mining being controlled exclusively by the state (Kulindwa et al. 2003). The Act gave citizens the opportunity to post mining claims in areas designated for prospecting and mining for minerals and engage in mining activities that did not require large expenditures and specialised equipment. Large-scale mining operations, however, were still only accepted if carried out in partnership with state enterprises (Jønsson and Fold 2009). The Act was followed by the Small Scale Mining Policy Paper of 1983, which encouraged Tanzanians to supplement their incomes by participating in mining activities (Chachage 1995).

In the 1980s, IMF-imposed structural adjustment coupled with prevailing low agricultural commodity prices, increasingly undermined the viability of the peasant agricultural sector (Bryceson 1999). Rural households coped with adversities by looking for alternative non-farm income sources. Small-scale mining provided an alternative to agriculture in mineral-rich parts of the country 
(Chachage 1995; Mwaipopo et al. 2004; Bryceson and Jønsson 2010). The 1980s saw a rapid succession of mineral discoveries of gold and gemstones. The fact that mineral smuggling was rampant is indicated by the meteoric rise in official gold exports after the breakup of the STAMICO monopoly at the end of the 1980s. Thereafter the government commissioned two national banks to buy gold at close to world market prices from anyone. The international gold price was on an upward trajectory. From virtually zero, Tanzania's official gold exports increased to four and a half tonnes in 1992 (Kulindwa et al. 2003; Phillips et al. 2001).

The 1990s and 2000s saw numerous gold and gemstone rushes and small-scale mining sites emerged throughout Tanzania (Figure 1). Geita district, in particular, experienced extremely rapid population expansion, doubling between the censuses of 1988 and 2002 with in-migration of people attracted by the opportunities of small and large-scale mining, especially Tanzania's biggest gold mine Geita Gold Mine owned by AngloGold Ashanti, to become the most populous district outside of Dar es Salaam (Lange 2006). Recently it has received regional status in recognition of the density of its population and its contribution to the economy.

Throughout the 1990s, hundreds of thousands of small-scale miners increasingly existed alongside western commercial exploration companies. The presence of the latter was triggered by a set of World-Bank-instigated investment and mining law reforms endorsed in the late 1990s containing the key elements required to attract foreign direct investment, i.e. the 1997 Mineral Policy, the 1997 Investment Act, the 1998 Mining Act, and the 1999 Mining Regulations. As intended, the new legislative framework was exceptionally effective in pulling in foreign direct investments, which since 1998 has amounted to more than US\$ 2.5 billion in the Tanzanian mining sector, especially in gold exploration and mining.

Besides a modern gemstone mine in the northeastern part of the country, all large-scale mines (six gold mines and one diamond mine) are located in the northwest around Lake Victoria in the regions of Tabora, Shinyanga, Mwanza, Geita, and Mara. Observing the number of gold sites ringed around Tabora region in Figure 1, we will refer to these as Tanzania's 'ring of gold' regions. In 2009, gold exports alone earned close to US\$ 1.4 billion. In only ten years, Tanzania has become one of the main African gold producers with annual outputs of around 50 tonnes (Roe and Essex 2009; Emel and Huber 2008).

\section{INSERT}

\section{Figure 1: Tanzania small-scale mining sites}

Source: Shand and Jønsson (2011) UPIMA project compiled from Jønsson’s Tanzanian small-scale mine list

News of a gold strike travels quickly with the increasingly ubiquitous use of mobile phones, generating a flash flood phenomenon as thousands of miners rush to the strike site to get a chance to work claims with the richest seams of ore (Jønsson and Bryceson 2009). Over the last two decades, miners have had many mineral sites to choose between and the numbers of small-scale miners have proliferated. In the mid-1990s, the number was estimated to be 550,000 (Tan Discovery 1996) and a recent World Bank-funded study conducted in 2011 estimates the number to be 685,000. ${ }^{6}$ As a result Tanzania's government recognises that the small-scale mining sector is a major provider of economic opportunities to rural communities (Tanzania 2005). In comparison, between 2003 and 2009, the number of employees within the large-scale mining sector varied between 6,000 and 12,000 people (Roe and Essex 2009). These employees, however, earned significantly more than the average smallscale miner.

\section{Small versus large-scale mining}

Following the endorsement of the 1998 Mining Act, an unprecedented debate on the mining sector in Tanzania began. Critics emphasised the limited revenues that the Tanzanian state received from minerals, especially gold, exported by large-scale mining companies, the often insensitive evictions (or resettlement schemes depending on the observers) of small-scale miners and farmers brought about by the same companies, and the fact that the legislation benefited large-scale mining at the expense of small-scale miners. With the 1998 Mining Act small-scale miners had the same opportunity to secure prospecting and mining licenses, as medium and large-scale companies. 
However, the restricted capacity of mining authorities to disseminate information on claim availability to small-scale miners as well as the how and when to acquire licenses favoured professionalised medium and large-scale mining companies which could secure licenses in mineral-rich areas before the majority of small-scale miners knew of the opportunity (Jønsson and Fold 2009; Carstens and Hilson 2009).

To address the criticism, President Kikwete set up a Presidential Mining Review Committee in 2007, which emphasized the need for an enhancement of the state's share of the production from large-scale mining. This was to be done through increased taxation and royalties and equity share ownership and secondly through improved working conditions for small-scale miners (Tanzania 2008). An immediate consequence of the report was a planned revision and reform of the mining legislation.

In July 2009, Tanzania launched a new Mineral Policy aimed at promoting increased integration between the mining sector and other sectors of the economy in order to improve mining's contribution to the national economy. ${ }^{7}$ The policy also prescribed the development and increased formalisation of the small-scale mining sector in order to facilitate sustainable development (Tanzania 2009).

In April 2010, parliament passed the 2010 Mining Act (Tanzania 2010) with the aim of achieving more equitable production and distribution arrangements for the financial proceeds of mining to alleviate voter dissatisfaction with the mining industry and to secure a continuous in-flow of FDI into the mining sector. The legislation designated more areas exclusively for small-scale mining purposes and imposed royalties on large-scale metal production up from 3 to $4 \%$ Large-scale mining companies have to be listed on the Dar es Salaam Stock Exchange, and the government has the possibility to acquire stakes in all future mining projects. Despite the new provisions towards smallscale mining, however, essentially the reformed legislation is still mainly targeting large-scale mining companies through an investor-friendly environment (Jønsson and Fold 2011). Thus, in Tanzania today, small-scale miners and large-scale mining companies exist side-by-side, though not hand-inhand.

\section{Migration to mining settlements}

While many who gravitate to small-scale mining settlements go bankrupt or lose their motivation given the physical danger associated with mining and the financial insecurity of not knowing if and when minerals will be found, there are nonetheless enough miners who do succeed to continually fuel people's expectations of lucrative earnings and replenish the migration flow (Jønsson and Bryceson 2009). Unlike the well-documented process of migration to towns for formal jobs or more latterly informal sector work, which transports individuals into urban lifestyles (Todaro 1969; 1997; Beall et al. 1999; Potts 2010), the rapid urbanisation of mining settlements affords individuals the experience of being catalysing agents for in situ urban birth and transformation. The first and subsequent migrants arrive in a rural setting that is taking on urban features as population concentration in the settlement outgrows reliance on local natural resources like water and firewood and starts contending with decreasing availability of land for food production (Bryceson and Mwaipopo 2010; Bryceson and Jønsson 2010).

Despite their rough and ready appearance, mining sites are usually quite cosmopolitan in character, attracting urban as well as rural-born migrants from close as well as very distant places. ${ }^{8}$ Muzzini and Lindeboom's $(2008,52)^{9}$ analysis of 2001-02 data reveals that migration activity was most pronounced in the central mining core regions, Tanzania's 'ring of gold', where in-migration to regional towns generally superceded migration to the regional capitals. ${ }^{10}$ Interestingly, Shinyanga's regional capital in fact recorded net out-migration, as did Singida's capital to a lesser extent. Both Singida and Tabora distinguished themselves as the only western regions that experienced net urban out-migration, which may reflect the lower quantity and quality of their mineral strike sites relative to the other mining regions (Muzzini and Lindeboom 2008).

What makes Tanzania's mine-led migration profoundly urban rather than rural in character is that the migration stream is not limited to mine labourers. It is highly diverse in skills and geographical origin with the potential to create a multi-occupational urban population from the outset. In the first instance, it is predominately male-biased as men rush to the mineral strike site, but within 
weeks women as well as many men are following with the intention of working in trade and service sector activities. Subsequent waves of non-mining migrants are responding to the same stimulus as miners. They anticipate higher earnings due to a sharp rise in demand for service activities on the part of miners with purchasing power far in excess of farmers in the surrounding rural countryside. Some women may be following husbands, but very large numbers will be part of chain migration through friendship networks, rather than family ties, seeking an independent income (Bryceson, Jønsson and Verbrugge forthcoming). Thus, the settlement grows with women's active involvement in tertiary services as well as mineral processing work.

Having discussed the growth of individual mining camps from a rural to urban scale of settlement, we will now consider Tanzania's unfolding pattern of urbanisation in order to identify when and where the impact of mining surfaces at a national level.

\section{Post-Independence Urbanisation Trajectory}

At national independence in 1961 Tanzania was an overwhelmingly rural country (Bryceson 1990). Only 7\% of the population lived in urban areas and Dar es Salaam dominated the urban hierarchy. As the de facto colour bar was lifted and white and blue-collar urban jobs became available to Africans, young men as well as women gravitated to the city. Dar es Salaam, the nation's capital, was their favoured destination. Hirst (1972) provided a perceptive analysis of Tanzania's urban hierarchy in 1969 when Dar es Salaam was at its zenith as the country's primate city in the first decade after national independence. The city's dominance in the nascent urban hierarchy became a government concern. By the 1970s, policymakers held the view that the capital's employment opportunities should not be allowed to expand out of proportion to the rest of the country. The implementation of a decentralisation policy involved posting civil servants and party officials to the capitals of mainland Tanzania's 20 regions as well as a growth pole strategy, aimed at spatially dispersing Tanzania's embryonic industries to seven cities (Nyerere 1972; Bryceson 1984). The latter did not achieve much success because, unlike the port city Dar es Salaam, Tanzania's other towns were constrained by costs of long distance goods transport to and from the coast and did not have the critical economies of scale and infrastructure that Dar es Salaam offered. However, government decentralisation of bureaucratic staff created nuclei of demand for urban goods and services that started to spur to the growth of the country's 20 regional capitals, thereby reducing the urban primacy of Dar es Salaam (Figure 2).

\section{INSERT}

\section{Figure 2: Dar es Salaam urban primacy, 1950-2010}

Source: United Nations, Population Division, 2004

A differentiated picture of urban growth emerged in the 1980s. On the whole, population growth slowed down in Dar es Salaam, the national capital and accelerated in the regional urban capitals as indicated by the steeper incline of the regional capitals' population growth between the 1967 and 1988 censuses (Figure 3).

\section{INSERT}

Figure 3: Urban population growth, 1957-2002

Sources: Tanzania censuses 1957, 1967, 1978, 1988, 2002

However, according to Tanzanian census data, there were distinct growth rates between capitals of mining regions and non-mining regions. In the inter-censal period between 1978 and 2002, mining regional capitals grew at 3.5\% per annum relative to non-mining capitals at $4.6 \%$ (Table 1 ). As smallscale mining spread, the growth of small towns in mining districts came to the fore. When one compares the growth rates of small towns of 10,000 or over with Dar es Salaam during the 1980s and 1990s, the small towns of mining regions are notable for their exceptional high annual growth relative to all other settlement types. Dar es Salaam, non-mining regional capitals and small towns in nonmining regions were all growing at roughly the same pace $(4.7 \%)$ while small towns in mining regions accelerated to $7.4 \%$. There was a tendency for traders and service sector provisioners to 
readily move from their residences in the regional towns to nearby mineral strike sites in anticipation of higher income, giving rise to the rapid growth of small town mining sites as $7.4 \%$ per annum.

Table 1: Annual urban growth rates by non-mining and mining regions ${ }^{11}$ and urban categories, 1978-2002

\begin{tabular}{|l|l|l|l|}
\hline Urban category & $\mathbf{1 9 7 8}$ & $\mathbf{2 0 0 2}$ & $\begin{array}{l}\text { Annual } \\
\text { growth rate } \\
\text { (\%) }\end{array}$ \\
\hline Dar es Salaam & 769,445 & $2,339,910$ & 4.7 \\
\hline $\begin{array}{l}\text { Non-mining regional } \\
\text { capitals }\end{array}$ & 424,614 & $1,246,059$ & 4.6 \\
\hline Mining regional capitals & 488,822 & $1,121,239$ & 3.5 \\
\hline $\begin{array}{l}\text { Towns in non-mining } \\
\text { regions }\end{array}$ & 252,634 & 784,840 & 4.8 \\
\hline Towns in mining regions & 163,841 & 911,428 & 7.4 \\
\hline
\end{tabular}

Source: Tanzania censuses 1978 and 2002. A breakdown of urban populations by region was not available for the 1988 census.

The urban literature to date has not focused on the changing pattern of urbanisation triggered by Tanzania's mining surge. This is understandable given the sudden and seemingly ephemeral nature of small-scale mining settlements, in addition to the fact that mine-led migration taking place between censuses goes largely unrecorded. To address this lacuna, we have combined the e-Geopolis data set ${ }^{12}$ with an up-to-date list of small-scale mining sites to categorise urban settlements into 'mining' and 'non-mining' regions and districts (Shand and Jønsson 2011). In this way, it has been possible to generate maps showing Tanzanian urban settlement growth change in relation to the location of smallscale mining sites.

Results of the last two censuses hint that Tanzania may be evidencing what Geyer (1996) refers to as a 'depolarisation' whereby core areas of urban growth relinquish their growth rate lead in favour of less populated locations (Geyer 1996). This involves 'differential urbanisation' in which fast followed by slower growth is experienced in successive waves that engulf groups of large, then intermediate-sized, and finally small cities. Geyer and Kontuly (1993) argue that this continuum characterises the evolution of urban systems in both developed and developing countries. By way of illustrating the process of depolarisation embedded in differential urbanisation, Dar es Salaam's urban primacy peaked in the early 1970s, superseded by the rapid growth rates of Tanzania's regional capitals in the decade thereafter, followed by the emergence of rapid small town growth particularly in mining regions (Bryceson 2006). This expanding depolarisation process is sometimes confusingly referred to as 'counterurbanisation' when it refers to small town growth at the expense of primate city growth (Geyer 1996). We prefer to avoid using 'counterurbanisation' in this context, reserving it instead for instances of absolute urban depopulation.

Figure 4 juxtaposes urban settlement growth over 20 year intervals, revealing how urban population growth has been heavily concentrated in the mining regions, especially in the last 20 years, with an increasingly obvious 'ring of gold' pattern emerging in the western part of the country, reflecting the location of mineral sites.

\section{INSERT}

Figure 4: Tanzanian small-scale mine sites relative to urban growth, 1950-2005

Source: Shand (2011) UPIMA project, compiled from Jønsson's Tanzanian small-scale mine list, e-Geopolis urban population data and the Second Administrative Level Boundaries data set project (SALB).

Comparing 1970 and 2005 in Figure 2 provides visual evidence of the clustering of urban settlements in gold-rich areas in Tanzania's northwestern mining frontier, namely Mara, Mwanza ${ }^{13}$ and Shinyanga regions (Bryceson and Mwaipopo 2010). Many of these areas are inhospitable, semi-arid areas prone to water shortages. Nonetheless, the lure of mineral strikes funnels the migration of often extremely large numbers to remote sites regardless of water availability and agricultural potential. While a comparison of the mineral site locations of Figure 1 and the urban settlement pattern of 
Figure 2 hint at a strong association between mining and population growth, further survey and census data would be required to pinpoint the strength of the association. ${ }^{14}$

Over time, in-migration is likely to taper and begin to be replaced with out-migration, particularly when small-scale miners reach a point of technological incapacity preventing them from digging deeper mining shafts or are evicted by the encroachment of large-scale mining. As male miners migrate elsewhere, they may leave behind a larger resident population than existed at the outset of the mining boom, including their wives, girlfriends and children. In the process, the gender ratio of the settlement is likely to tip from a male to female bias. Beyond the changing gender ratio, counter-urbanisation in the form of absolute depopulation may take place in some settlements, with some eventually becoming 'ghost towns', abandoned for lack of viable livelihoods. In locations with good water supplies, fertile land and proper road connections, urban growth is more likely to be sustained, bolstered by government, civil society and private sector infrastructural investment in roads, schools, health clinics and religious centres.

In these cases, the settlement is in a position to draw additional migrants from rural areas, which are attracted to the superior amenities. This, however, depends on some degree of alternative employment prospects and/or the possibility of an agrarian fallback. This outcome points to a another pathway through which mineral wealth promotes urban growth as illustrated by Katoro-Buseresere, a settlement of over 30,000 people (2002 census) located in the northwest section of Tanzania's ring of gold on the border between Geita and Kagera regions, which has no direct mineral wealth, but instead is a thriving market town with an extensive service sector, that has attracted the custom of traders, transporters and small-scale miners (Bryceson 2011). Demographically, during the boom years of the 1990s, its population grew very rapidly, biased towards female rather than male migrants. Overwhelmingly their motivation for migration was the search for trade and better opportunities rather than marriage or employment expectations. Its position on the main road to Uganda, straddling two regions has given it additional commercial potential. A number of small-scale gold mining sites surrounding the town make it a favourite place for miners when they have cash to splash around. The livelihood patterns of the settlement range across trade and agriculture, giving it a far more stable foundation for growth, compared with the fluctuating fortunes of pure mining settlements (Bryceson and Mwaipopo 2010).

\section{Ring of gold promises and problems for Tanzania's urban future}

Having traced Tanzania's mining history in tandem with its urban history, we have identified three mineral-related stimulants to urban growth: first, sites of regional or international trade in minerals, exemplified by Kilwa, a cosmopolitan city of the medieval past that thrived as an Indian Ocean gold trading centre. Second are locations of on-site mineral production as illustrated by the Lupa gold rush during the colonial period, and Geita, a large-scale corporate mining town of the present. Both feature strong population growth and economic diversification. Third are sites of secondary service development, notably Katoro-Buseresere, which rely on the increased purchasing power of regional mining wealth.

Tracing the processes of mineralisation and urbanisation, we have observed that colonial gold and diamond production in Tanganyika were not dominant forces in the territorial economy. However, during the world depression of the 1930s, as the price of gold rose, the country experienced a localized gold rush in Lupa that is incomparable with the magnitude of the country's present surge in gold production. A spiralling gold price amidst global economic uncertainty has spurred smallscale miners' discovery of a proliferation of gold sites, especially in Tanzania's ring of gold. Miners have rushed to these sites in the hopes of profiting. In the process, many remote rural locations have quite suddenly grown into sizeable small towns. Gold now constitutes more than $50 \%$ of the value of the nation's exports. Small-scale production of a clandestine nature has been giving way to more open small-scale mining that now competes with large-scale mining interests for mineral rights.

The analysis here has marshalled evidence to suggest that a synergy between mining and urban growth is currently underway, most heavily influenced, in the first instance, by small-scale miners' migration to mineral rush sites. The locational shift of an economically active population has catalysed rapid secondary city growth in the country's mineral-rich regions. Our analysis of Tanzanian census data indicates that urban growth has progressed from an early period of primate city 
dominance (up to the 1970s), through a period of rapid growth of intermediate secondary cities, notably the country's regional capitals during the 1980s, to a third stage in which the rapid growth rate and proliferation of small towns, specifically in mineral-rich areas, is now pronounced. The threestage pattern of successive fast then slow waves of growth of the primate city, intermediate cities and finally small towns, identified by Geyer and Kontuly (1993), is reflected in the settlement growth pattern of Tanzania's urban hierarchy.

In addition to rapid population expansion, a proliferating economic division of labour and the emergence of internal social stratification and governance are emerging in the youthful mining settlements throughout the country's mining regions. The overall demographic picture is extremely dynamic. This contribution represents a preliminary step in documenting Tanzania's mining and urbanising synergetic trajectory. The 2012 census will provide a vital update for a decade in which Tanzania's mining has become the nation's leading economic sector. Identifying associated demographic trends is key to the formulation of timely spatial and economic policies. Furthermore, understanding the specific dynamics of urbanisation is requisite for prioritising infrastructural investment and social services to encourage productive and welfare-enhancing benefits.

Tanzania is in an enviable position at present. From 2001, its trade balance has been in surplus given its rising gold exports (Roe and Essex 2009, 28). In 2010, the value of the country's exports superseded imports (Bank of Tanzania 2010). The exceptionally high price of gold in the current global recession and the mineral richness of the country combined to provide an important window of opportunity in Tanzania's economic history. Tanzania's mineral treasure-trove must be secured as a credit rather than a curse by moving rationally from the eureka discoveries of small-scale miners to judicious national investment in infrastructure and well being for the national population. Distributive justice in terms of jobs and residential settlement is paramount.

Timely infrastructural planning and investment in small towns can avert the problems of infrastructural congestion and inadequacy currently so apparent in Dar es Salaam and the secondary cities. Rapid, unplanned urbanisation and lack of economic diversification, generating a host of troubles in the form of labour displacement and impoverishment for vast numbers of Tanzanians caught in the transition from rural agrarian to urban career pursuits, is avoidable with careful planning. Tanzania faces a literal and figurative golden investment opportunity that should not be squandered. Recent Tanzania mining legislation has taken small-scale miners' interest into account, but mining’s impact on the country will largely depend on distributive follow-up settlement planning, infrastructural investment and employment policies in an increasingly urbanised country.

\section{Notes on Contributors:}

Deborah Fahy Bryceson is a Reader in the Geographical and Earth Sciences School at the University of Glasgow. She has published on the theme of African deagrarianisation and livelihood diversification including Farewell to Farms: De-Agrarianization and Employment in Africa (Ashgate 1997), Disappearing Peasantries: Rural Labour in Africa, Asia and Latin America (2000), African Urban Economies (2006), and How Africa Works: Occupational Change, Identity and Morality in Africa (2010). She currently coordinates the Urbanization and Poverty in Mining Africa (UPIMA) research programme. During the last five years her work has concentrated on documenting the world of East African artisanal mining. She can be contacted at: dfbryceson@bryceson.net

Jesper Bosse Jønsson is Research Fellow at the School of Geographical and Earth Sciences at the University of Glasgow. He coordinated the Centre for Sustainable Artisanal and Small-Scale Mining (SASMIN) located at the University of Copenhagen before taking up his current position as international field coordinator in the UPIMA research programme. He has recently published a book about the world travels of a Danish gold miner at the turn of the $20^{\text {th }}$ century entitled Guldgraveren: Danskeren der fandt Kong Salomons Miner and has published numerous journal articles on Tanzanian artisanal mining. He can be contacted at: jesper.jonsson@glasgow.ac.uk

Crispin Kinabo is a Senior Lecturer at the Department of Geology, University of Dar es Salaam, Tanzania. He has more than 20 years of professional experience on small-scale mining with interest in its socio-economic aspects, demography and technology development for artisanal and small-scale mining. Since 1998 he has coordinated the Small Scale Mining Project within the Southern African Network for Training and Research on the Environment (SANTREN) and is a steering committee member on Minerals, Mining and Sustainable 
Development (MSSD) for the SADC countries. He has published several book chapters on the socio-economic impact of artisanal mining in developing countries. He can be contacted at: kinabo_2003@yahoo.co.uk

Mike Shand (FRSGS, FBCartS) is a GIS cartographer and Honorary Research Fellow at the University of Glasgow involved in GIS mapping, research and teaching. His career encompasses numerous mapping projects, research and consultancies in Tanzania, Nigeria, South Africa, India, Philippines, Saudi Arabia, Iran, and Bosnia Herzegovina. Currently he is a team member of the DfiD/ESRC-funded UPIMA research in Tanzania, Ghana, Angola; the Medical Research Council-funded project on "Designing large-scale rabies vaccination programs in Tanzania, Philippines, Bali, South Africa"; and an BBSRC/ESRC/NIH-funded project on "The impact and social ecology of bacterial zoonoses in northern Tanzania”. His recent publication is: The wild heart of Africa, 110 years of the Selous Game Reserve, Tanzania. 2009. Baldus R.D. He can be contacted at: mike.shand@glasgow.ac.uk

\section{References:}

Beall, J., N. Kanji and C. Tacoli 1999. African urban livelihoods: Straddling the rural-urban divide. In Urban poverty in Africa: From understanding to alleviation. ed. S. Jones and N. Nelson, 160-68. London: Intermediate Technology Publications.

Bryceson, D.F. 1984. Urbanisation and agrarian development in Tanzania with special reference to secondary cities. London: International Institute for Environment and Development.

Bryceson, D.F. 1990. Food insecurity and the social division of labour, 1919-1985. London: Macmillan.

Bryceson, D.F. 1999. African rural labour, income diversification and livelihood approaches: A long-term development perspective. Review of African Political Economy, no. 80: 171-89.

Bryceson, D.F. 2009. Sub-Saharan Africa's vanishing peasantries and the specter of a global food crisis. Monthly Review. July-August: 48-62.

Bryceson, D.F. 2011. Birth of a market town in Tanzania: Towards narrative studies of urban Africa. Journal of Eastern African Studies 5, no. 2: 274-93.

Bryceson, D.F. and J.B. Jønsson 2010. Gold digging careers in rural Africa: Small-scale miners' livelihood choices. World Development 38, no. 3: 379-82.

Bryceson, D.F. and R. Mwaipopo 2010. Rural-urban transitions in Tanzania’s Northwest mining frontier. In Rural-urban dynamics: Livelihoods, mobility and markets in African and Asian frontiers. eds J. Agergaard, N. Fold and K.V. Gough, 158-74. London: Routledge.

Bryceson, D.F., J.B. J Jønsson and H. Verbrugge. Forthcoming. Loosely-woven Love: Conjugal Bonds and Family Formation in Artisanal Mining Settlements. In Mineralizing Africa: Artisanal mining and social change. eds D.F. Bryceson, E. Fisher, J.B. Jønsson and R. Mwaipopo. forthcoming.

Bryceson, D.F. 2006. Vulnerability and viability of East and Southern Africa's apex cities. In African urban economies: Viability, vitality or vitiation? D.F. Bryceson and D. Potts. 319-40. London: Palgrave Macmillan.

Carstens, J. and G. Hilson. 2009. Mining and grievance in rural Tanzania. International Development Planning Review 31, no. 3: 301-26.

Chachage, C.S.L. 1995. The meek shall inherit the earth but not the mining rights: The mining industry and accumulation in Tanzania. In Liberalised Development in Tanzania. ed. P. Gibbon. 37-108. Uppsala: Nordiska Afrikainstitutet.

Dickson, J. 1925. Lupa diary. Oxford University: Rhodes House, RH Mss. Afr. s.738.

Drechsler, B. 2001. Small-scale mining and sustainable development within the SADC region. London: International Institute of Environment and Development/World Business Council for Sustainable Development.

Emel, J. and M.T. Huber. 2008. A risky business: Mining, rent and the neoliberalisation of 'risk', Geoforum 39, no. 3: 1393-1407.

Geyer, H.S. 1996. Expanding the theoretical foundation of the concept of differential urbanisation. Tijdschrift voor Economische en Sociale Geografie 87, no. 1: 44-59.

Geyer, H.S. and T. Kontuly. 1993. A theoretical foundation for the concept of differential urbanisation. International Regional Science Review 17, no. 2: 157-77.

Hirst, M.A. 1972. A functional analysis of towns in Tanzania. Tijdschrift voor Econ. en Soc. Geografie 64, no. 1: 39-51.

Ibn Battuta 1962. The travels of Ibn Battuta, trans. by H.A.R. Gibb, 4 vols. London: Hakluyt Society.

ILO (International Labour Organisation) 1999. Social and labour issues in small-scale mines: Report for discussion at the Tripartite Meeting on Social and Labour Issues in Small-scale Mines. Geneva: International Labour Organisation. 
Jønsson, J. B. and N. Fold. 2009. Handling uncertainty: Policy and organisational practices in Tanzania’s smallscale gold mining sector. Natural Resources Forum 33, no. 3: 211-220.

Jønsson, J.B. and D.F. Bryceson. 2009. Rushing for gold: Mobility and small-scale mining in East Africa. Development and Change 40, no. 2: 249-79.

Jønsson, J.B. and N. Fold. 2011. Mining 'from below': Taking Africa’s artisanal miners seriously. Geography Compass 5, no. 7: 479-493.

Kulindwa, K., O. Mashinadano, F. Shechambo and H. Sosovele. 2003. Mining for sustainable development in Tanzania, Dar es Salaam: Dar es Salaam University Press.

Lange, S. 2006. Benefit streams from mining in Tanzania: Case studies from Geita and Mererani. Bergen: Christian Michelson Institute, R2006.1.

Lemelle, S.J. 1986. Capital, state and labor: A history of the gold mining industry in colonial Tanganyika 18901942. Ph.D thesis, University of California at Los Angeles.

Mitchell, P. 2005. African connections: Archaeological perspectives on Africa and the wider world. Walnut Creek CA: Altamira Press.

Moon, K. 2005. Kilwa Kisiwani: Ancient port city of the East African coast. Dar es Salaam: Tanzania Printers/Government of Tanzania.

Muzzini, E. and W. Lindeboom. 2008. The urban transition in Tanzania: Building the empirical base for policy dialogue, World Bank stock no. 37274, http://siteresources.worldbank.org/CMUDLP/ Resources/ Tanzania_wp.pdf.

Mwaipopo, R., W. Mutagwaba, W. D. Nyanga and E. Fisher.2004. Increasing the contribution of artisanal and small-scale mining to poverty reduction in Tanzania. London: Department for International Development.

Nyerere, J.K. 1972. Decentralisation. Dar es Salaam: Government Printer.

Pearson, M.N. 1998. Port cities and intruders: The Swahili coast, India, and Portugal in the early modern era. Baltimore: The Johns Hopkins University Press.

Phillips, L.C., H. Semboja, G.P. Shukla, R. Sezinga, W. Mutagwaba, B. Mchwampaka, G. Wanga, G. Kahyarara and P.C. Keller 2001. Tanzania's precious mineral boom: Issues in mining and marketing, Washington DC: USAID.

Potts, D. 2010. Circular migration in Zimbabwe and contemporary Sub-Saharan Africa. Suffolk UK: James Currey.

Roberts, A. D. 1986. The gold boom of the 1930s in Eastern Africa. Journal of the Royal African Society 85, no. 341: 545-562.

Roe, A.R. and M. Essex 2009. Mining in Tanzania - What future can we expect?. Paper to the ICMM Workshop on Mining in Tanzania, Dar es Salaam, 18 May, 2009 (revised 28 June, 2009), Oxford: Oxford Policy Management.

Shand, M. 2011. Tanzanian small-scale mining sites relative to urban growth, 1950-2005, University of Glasgow, UPIMA project.

Shand, M. and J.B. Jønsson. 2011. Tanzania gold mines and minerals map, University of Glasgow, UPIMA project.

Tan Discovery. 1996. Final report on baseline survey and preparation of development strategy for small scale and artisanal mining program. Dar es Salaam: Ministry of Energy and Minerals and Washington DC: World Bank.

Tanganyika Territory. 1938. Report of the committee appointed to consider and advise on questions relating to the supply and welfare of native labour in the Tanganyika Territory. Dar es Salaam: Government Printer.

Tanzania, Bank of. 2010. Economic and operations reports, Dar es Salaam.

Tanzania, United Republic of. 1982. 1978 population census. Dar es Salaam: Population Division, Bureau of Statistics.

Tanzania, United Republic of. 1991. 1988 population census, Dar es Salaam: National Bureau of Statistics.

Tanzania, United Republic of. 1997. Mineral policy of Tanzania, Dar es Salaam: Ministry of Energy and Minerals, Government Printer.

Tanzania, United Republic of. 1997. Investment Act of Tanzania. Dar es Salaam: Government Printer.

Tanzania, United Republic of. 1998. The Mining Act. Dar es Salaam: Ministry of Energy and Minerals, Government Printer.

Tanzania, United Republic of. 1999. The Mining Regulations. Ministry of Energy and Minerals, Dar es Salaam: Government Printer.

Tanzania, United Republic of. 2005. National strategy for growth and reduction of poverty. Dar es Salaam: Vice President's Office, Government Printer.

Tanzania, United Republic of. 2008. Bomani report of the Presidential Mining Review Committee to advise the government on oversight of the mining sector, vol. 2, translated by Paperworks Associates Tanzania on behalf of Policy Forum. http://coet.udsm.ac.tz/biofuel\%20documents/ 7.\%20Bomani\%20Report\%20\%20English.doc (accessed 5 June 2010). 
Tanzania, United Republic of. 2009. The new mineral policy of Tanzania. Ministry of Energy and Minerals, Dar es Salaam: Government Printers.

Tanzania, United Republic of. 2010. The Mining Act 2010. Ministry of Energy and Minerals, Dar es Salaam: Government Printers.

Thompson, M. 1936-65. Melvyn's letters: A collection of letters and images written by and about Melvyn and Winona Thompson”. (Canadian geologist working in Tanzanian gold mining), http://www.melvynsletters.ca/

Todaro, M. 1969. A model of labor migration and urban unemployment in less developed countries. American Economic Review 104: 387-413.

United Nations 2004. World urbanisation prospects: The 2003 revisions. New York: Economic and Social Affairs, Population Division.

\section{Notes:}

1 'Small-scale mining' is labour-intensive and involves low capital investments, low degree of mechanisation, basic equipment, and a high degree of occupational risk.

2 Decline was connected with a dispute over royal succession and the rising importance of Mombasa and Malindi in trade with India (Moon 2005).

3 Before the Portuguese built Fort Jesus, Mombasa had already become the favoured port of call for Indian sea-faring merchants given that the strength and timing of the monsoonal winds were superior to those of Kilwa (personal communication with Prof. Abdul Sheriff, 5 March, 2011).

4 The value of gold exports as a percentage of total exports was 6\% in 1930-31 and 11\% in 1936.

5 Lemelle $(1986,332)$ perceives the number to be an underestimation, as many of the miners from the neighbouring countries were not counted. At the time the population of Tanganyika would have been close to 6 million. Assuming that half the population was economically active, less than $1 \%$ would have been engaged in mining.

6 One of the authors of this chapter, Crispin Kinabo, participated in the study, which has yet to be published.

7 This entailed: 1) facilitating forward and backward linkages of mining with other sectors of the Tanzanian economy including the expansion of mining company's procurement of local goods and services in place of imports; 2) giving preference to the employment of Tanzania's trained mining experts over expatriates; and 3) narrowing the gap between foreign profits from mining and revenues to the Tanzanian government.

8 Bryceson and Mwaipopo (2010) found that approximately 20\% of migrants to the diamond and gold mine sites they surveyed were born in urban areas.

9 Muzzini and Lindeboom's (2008, 80) study examined census data from 1988 and 2002 focussing on: the 'cities' of Dar es Salaam, Mwanza and Mbeya; the 'municipalities' of Moshi, Tabora, Iringa, Dodoma, Songea, Mtwara, Sumbawanga, Singida, Kigoma, Bukoba, Musoma, Arusha, Morogoro, Shinyanga, Kinondoni, Temeke, Ilala; and the ‘towns’ of Kibaha, Babati, Korogwe and Lindi $(2008,79)$ as well as 77 regional townships.

10 This was the case in Mwanza, Shinyanga, Mara, Rukwa and Mbeya regions. Only Kagera and Tabora regions, where mining activities are less significant, recorded larger regional capital growth relative to regional town growth (Muzzini and Lindeboom 2008, 52).

11 'Mining region' in this categorisation refers to Tanzania's main gold and diamond mining regions (Mara, Mwanza, Shinyanga, Kagera, Singida, Tabora, Rukwa, Mbeya, Tanga), identified on the basis of being regions where $25 \%$ or more of the rural districts have known small-scale mining sites of gold or diamonds. Note Morogoro, Dodoma, Arusha, Manyara, Mtwara, Lindi and Ruvuma regions with mining sites of precious stones (emeralds, rubies, sapphires, etc) achieve this level of prevalence in production of precious stones but not diamonds or gold and are therefore excluded from our mining region category.

12 The e-Geopolis urban data set provides population estimates of Tanzanian settlements of over 10,000 people by decade throughout the $20^{\text {th }}$ century based on published census data as well as other official records. See www.e-geopolis.eu.

13 In Map 2, Mwanza region includes the newly designated region of Geita.

14 There are other economic stimulants to growth in the gold ring area, notably a boom in Lake Victoria fisheries, rice and cotton farming, and livestock keeping. 